\title{
The two-week wait and other initiatives to improve cancer diagnosis: has it altered survival? The answer is unclear - the evidence is too weak.
}

\author{
Dr Clare Bankhead, University Research Lecturer, Nuffield Department of Primary \\ Care Health Sciences, University of Oxford, Oxford, OX2 6GG
}

For many years, international comparisons have shown large differences in cancer survival between high-income countries, despite good access to health care, with the UK amongst the lowest ranked (Berrino et al, 2007; Coleman et al, 2008; Coleman et al, 2011; Angelis et al, 2014). It is known that later stage at diagnosis is a significant contributory factor to reduced survival (McPhail et al, 2015) and that for some cancers such as bladder, lung and ovarian there are lower survival rates at every stage, whereas for breast, prostate and melanoma reduced survival is only evident in advanced stage cancers (Public Health England, 2016). Since the introduction of the National Cancer Plan in 2000 (Department of Health, 2000) there have been concerted efforts to diagnose cancer earlier by reducing delays at all stages of the patient pathway.

The patient pathway comprises the following intervals: patient interval (between symptom onset and seeing a GP); primary care interval (also known as the diagnostic interval) between first GP appointment and referral to a specialist; and secondary care interval (between referral and definitive diagnosis) (Olesen, Hansen, Vedsted, 2009; Walter et al, 2012). This can help frame the problem, and it is now recommended that a model of diagnostic intervals is embedded within research focussing on early cancer diagnosis (Weller et al, 2012).

How important is the patient interval? Analysis of data from almost 11,000 patients diagnosed with cancer showed that the mean patient interval was longer than the primary care interval for many cancers, and for 10 cancers they were two- to five-times greater indicating that there is scope for improving patient presentations to primary care (Lyratzopoulos et al, 2015).

There have been various initiatives which aim to reduce the patient interval by increasing levels of cancer awareness. A systematic review of the literature concluded that individuallevel interventions lead to a modest increase in cancer awareness, but there was insufficient evidence to draw conclusions about the impact on delays in presentation. There was limited evidence that community-level interventions may reduce stage at presentation for breast 
cancer, malignant melanoma and retinoblastoma (Austoker et al, 2009). More recently, an on-going series of public health campaigns (the 'Be Clear on Cancer Campaigns') have been running in England since 2010 (Public Health England, 2017). The latest published evaluation of these campaigns has shown statistically significant increases in cancer awareness, GP attendance, urgent referrals, and diagnostic tests, but a lower proportion of referrals diagnosed with cancer (conversion rates). Cancer incidence rates, stage at diagnosis and survival rates have not yet been reported (Cancer Research UK, 2014).

The diagnostic interval in primary care has been addressed by setting referral guidelines and target times for specialist referrals, first introduced in the NHS Cancer Plan in 2000 (Department of Health, 2000 ), and most recently updated in 2015 (NICE, 2015). These targets (the two-week referral guidelines) state that patients with symptoms suggestive of suspected cancer should wait no longer than two weeks from urgent GP referral for suspected cancer to an appointment with a specialist.

So what has been the impact of the two-week referral guidelines? The numbers of urgent referrals have increased each year, from 903,000 in 2009/10 to over 1.5million in 2014/ (National Cancer Intelligence Network, 2016). This has been applauded by some as evidence of getting people to 'step up' and seek help, whilst others say it is overwhelming secondary care. In line with the increasing number of referrals, the cancer detection rate has increased from $42.3 \%$ to $48.4 \%$ and the conversion rate has decreased from $10.8 \%$ to $8.2 \%$ over the same time period (National Cancer Intelligence Network, 2016).

Has the time to diagnosis altered with the introduction of the two-week referrals? Analyses of routine data have compared the diagnostic interval for two cohorts of symptomatic cancer patients, before and after the introduction of the two-week referral guidelines. They showed that overall, the diagnostic interval was significantly reduced by 5.4 days (95\% CI $2.4-8.5$ days) between the two time periods, but there was large variation between the 15 cancers included, and for some cancers, presentations with symptoms not included in the referral guidelines led to an increase in time to diagnosis (Neal et al., 2014). Data from Denmark show a very similar picture, although interestingly the reductions observed after the introduction of a standardised cancer pathway were larger than those observed in the UK (Jensen et al, 2015). 
So the diagnostic interval has shortened for several cancers, but does reducing this interval lead to survival differences? A Danish prospective study described the association between diagnostic interval and five-year mortality for five cancers and reported that longer diagnostic intervals were associated with increased mortality. They also reported that very short diagnostic intervals were also associated with reduced mortality. (Tørring et al, 2013).

A systematic review comparing improved outcomes and time to diagnosis could not produce any pooled estimates of effect due to heterogeneity in methods, reported outcomes and in the definitions of the exposure (time to diagnosis). The authors did, however, conclude that in more recent research that took the waiting time paradox into account, there was some evidence of longer diagnostic intervals being associated with worse outcomes (Neal et al, 2015).

However, an analysis of routinely collected primary care data did not highlight any consistent patterns between diagnostic interval and survival (Redaniel et al, 2015).

So far, the literature is reporting on only parts of the pathway between interventions to improve diagnosis and hard outcomes such as survival. So is there any direct evidence that the urgent referral pathway increases survival? The closest we get, is an analysis of GP practice-level data, which includes data from almost a quarter of a million cases of cancer diagnosed in the UK between 2009 and 2013. It showed that at a GP practice level, mortality was reduced in practices that were higher users of the two-week wait pathway than average or low referrers (Møller et al , 2015).

Can we learn anything from international comparisons? The International Cancer Benchmarking Partnership (ICBP), a research collaboration between six countries (Australia, Canada, Denmark, Norway, Sweden and the UK), are studying the variations between the countries, and investigating potential differences to develop our understanding of the reasons for the observed disparities (Butler et al, 2013).

Data from this collaboration has shown wide variations in stage-specific survival between the countries, suggesting that other factors are also important such as differences in treatment or access to treatment (Maringe et al, 2012; Maringe et al, 2013; Walters et al, 2013a; Walters et al 2013b). 
Investigation of the patient interval showed that symptom awareness of all cancer types were similar across the countries involved in ICBP, with slightly lower awareness in Sweden than in the other 5 countries. However, respondents to the survey in the UK reported higher levels of barriers to health-seeking behaviours, even if symptomatic, and were particularly worried about wasting the doctor's time which may lead to longer patient intervals. (Forbes, BJC 2013).

A jurisdiction-level analysis showed a positive correlation between improved survival rates and willingness to act definitively (including referring to a specialist) when faced with 5 multi-staged vignettes of patients presenting with symptoms suggestive of cancer (Rose et al, 2015), but adherence to guidelines was not associated with 1-year survival (Nicholson et al, 2016).

In summary, initiatives to improve early diagnosis may raise cancer awareness in the population, and perhaps reduce the patient interval; can reduce the diagnostic interval between presentation and specialist appointment; and there may be survival benefits associated with increased willingness to refer, or actual referral. What is currently lacking is research that directly addresses whether the introduction of the 2-week wait referral process has led to improved survival amongst individuals. Surely, it must be time now to link information from sources such as the cancer waiting times database, with staging, time to treatment and survival data to analyse, at the individual-level, the impact of the 2 week wait on cancer survival?

\section{References}

Austoker J, Bankhead C, Forbes LJL, Atkins L, Martin F, Robb K, Wardle J, Ramirez AJ.(2009). Interventions to promote cancer awareness and early presentation: systematic review. British Journal of Cancer, 101, S31-S39

Berino F, De Angelis R, Sant M, Rosso S, Bielska-Lasota M, Coebergh JW, Santaquilani M: the Eurocare Working Group (2007). Survival for eight major cancers and all cancers combined for European adults diagnosed in 1995-99: results of the EUROCARE-4 study. Lancet Oncol, 8(9), 773-83 
Butler J, Foot C, Bomb M, Hion S, Coleman M, Bryant H, Vedsted P, Hanson J, Richards M, the ICBP Working Group (2013). The International Cancer Benchmarking Partnership: An international collaboration to inform cancer policy in Australia, Canada, Denmark, Norway, Sweden and the United Kingdom. Health Policy, 112(1-2), 148-155

Cancer Research UK . Be Clear on Cancer evaluation update 2014.

http://www.cancerresearchuk.org/sites/default/files/evaluation_results_2014.. Accessed $27 / 01 / 2017$

Coleman MP, Quaresma M, Berrino F, Lutz M. De Angelis R, Capocaccia R, Baili P, RAchet B, Gatta G, HakulinenT, Michel A, Sant M, Weir HK, Elwood JM, Tsukuma H, Koifman S, E Silva GA, Francisci S, Santaquilani M, Verdecchia A, Storm HH, Young JL,: CONCORD Working Group. (2008). Cancer survival in five continents: a worldwide population-based study (CONCORD). Lancet Oncol, 9(8),730-56.

Coleman MP, Forman D, Bryant H, Butler J, Rachet B, Maringe C, Nur U, Tracey E, Coory M, Hatcher J, McGahan CE, Turner D, Marrett L, Gierstorff ML, Johannesen TB, Adolfsson J, Lambe M, Lawrence G, Meecham D, Morris EJ, Middleton R, Steward J, Richards MA,: ICBP Module 1 Working Group (2011). Cancer survival in Australia, Canada, Denmark, Norway, Sweden and the UK, 1995-2007 (the International Cancer Benchmarking Partnership): an analysis of population-based cancer registry data. Lancet, 377 (9760), 127 38.

De Angelis R, Sant M, Coleman MP, Francisci S, Baili P, Pierannunzio D, Trama A, Visser O, Brenner H, Ardanaz E, Bielska-Lasota M, Engholm G, Nennecke A, Siesling S, Berrino F, Capocaccoa R: EUROCARE-5 Working Group. (2014). Cancer Survival in Europe 19992007 by country and age: results of EUROCARE-5 - a population-based study. Lancet Oncol, 15(1), 23-34.

Department of Health. The NHS Cancer Plan, 2000. Available at: http://webarchive.nationalarchives.gov.uk/20130107105354/http://www.dh.gov.uk/prod_cons um_dh/groups/dh_digitalassets/@dh/@en/documents/digitalasset/dh_4014513.pdf. Accessed 27/01/2017.

Forbes LJL, Simon A, Warburton F, Boniface D, Brain KE, Dessaix A, Donnelly C, Haynes K, Hvidberg L, Lagerlund M, Lockwood G, Tishelman C, Vedsted P, Vigmostad MN, 
Ramirez AJ, Wardle J and the ICBP Module 2 Working Group (2013). Differences in cancer awareness and beliefs between Australia, Canada, Denmark, Norway, Sweden and the UK (the International Cancer Benchmarking Partnership): do they contribute to differences in cancer survival. British Journal of Cancer, 108, 292-300.

Jensen H, Tørring ML, Olesen F, Overgaard J, Fengergron M, Vedsted P (2015). Diagnostic intervals before and after implementation of cancer patient pathways - a GP survey and registry based comparison of three cohorts of cancer patients. BMC Cancer, 15, 308 Lyratzopoulos G, Saunders CL, Abel GA, McPhail S, Neal RD, Wardle J, Rubin GP (2015). The relative length of the patient and the primary care interval in patients with 28 common and rarer cancers. British Journal of Cancer, 112, S35 - S40.

Maringe C, Walters S, Butler J, Coleman MP, Hacker N, Hanna L, Mosgaard BJ, Nordin A, Rosen B, Engholm G, Gjerstorff ML, Hatcher J, Johannesen TB, McGahan CE, Meechan D, Middleton R, Tracey E, Turner D, Richards MA, Rachet B, \& The ICBP Module 1 Working Group (2012). Stage at diagnosis and ovarian cancer survival: Evidence from the International Cancer Benchmarking Partnership. Gynecologic Oncology, 127(1), 75-82.

Maringe C, Walters S, Rachet B, Butler J, Fields T, Finan,Maxwell R, Nedreb B, Påhlman L, Sjövall A, Spigelman A, Engholm G, Gavin A, Gjerstorff ML, Hatcher J, Johannesen TB, Morris E, McGahan CE, Tracey E, Turner D, Richards MA, Coleman MP \& The ICBP Module 1 Working Group (2013) Stage at diagnosis and colorectal cancer survival in six high-income countries: A population-based study of patients diagnosed during $2000-2007$, Acta Oncologica, 52(5), 919-932.

McPhail S, Johnson S, Greenberg D, Peake M, Rous B (2015). Stage at diagnosis and early mortality from cancer in England. British Journal of Cancer, 112, S10-S115.

Møller H, Gildea C, Meechan D, Rubin G, Round T, Vedsted P (2015). Use of the English urgent referral pathway for suspected cancer and mortality in patients with cancer: cohort study. BMJ, 351, h5102

National Cancer Intelligence Network Data Briefing. Trends in cancer waiting times metrics, England 2009/10 to 2014/15. Available from www.ncin.org.uk/view?rid=310. Accessed $29 / 01 / 2017$ 
Neal RD, Din NU, Hamilton W, Ukoumunne OC, Carter B, Stapley S, Rubin G (2014). Comparison of cancer diagnostic intervlas before and after implementation of NICE guidelines: analysis of data from the UK General Practice Research Database. British Journal of Cancer, 110, S84-S92.

Neal RD, Tharmanathan P, France B, Din NU, Cotton S, Fallon-Ferguson J, Hamilton W, Hendry A, Hendry M, Lewis R, Macleod U, Mitchel ED, Pickett M, Rai T, Shaw K, Stuart N, Tørring ML, Wilkinson C, Williams B, Williams N, Emery J (2015). Is increased time to diagnosis and treatment in symptomatic cancer associated with poorer outcomes? Systematic review. British Journal of Cancer, 112, S92 - S107.

NICE, 2015. Suspected cancer: recognition and referral. NICE guideline [NG12] Published date: June 2015. https://www.nice.org.uk/guidance/ng12. Accessed 27/01/2017

Nicholson BD, Mant D, Neal RD, Hart N, Hamilton W, Shinkins B, Rubin G, Rose PW (2016). International variation in adherence to referral guidelines for suspected cancer: a secondary analysis of survey data. British Journal of General Practice, DOI: 10.3399/bjgp16X683449

Olesen F, Hansen RP, Vedsted P. (2009). Delay in diagnosis: the experience in Denmark. British Journal of Cancer, 101, 55-58.

Public Health England. Stage at diagnosis 2012-2014 and one year cancer survival in England. National cancer registration and analysis data briefing. September 2016. Available from http://www.ncin.org.uk/publications/survival_by_stage. Accessed 27/01/2017

Public Health England, 2017. 'Be Clear on Cancer' Campaign. http://www.cancerresearchuk.org/health-professional/early-diagnosis-activities/be-clear-oncancer. Accessed 27/01/2017

Redaniel MT, Martin RM, Ridd MJ, Wade J, Jeffreys M (2015). Diagnostic intervals and its association with breast, prostate, lunch and colorectal cancer survival in England: historical cohort study using the Clinical Practice Research Datalink. PLOS One, 10(5), e0126698 Rose PW, Rubin G, Perera-Salazar P, Almberg SS, Barisic A, Dawes M, Grunfeld E, Hart N, Neal RD, Pirotta M, Sisler J, Konrad G, Toftegaard BS, Thulesius H, Vedsted P, Young J, 
Hamilton W and the ICBP Module 3 Working Group (2015). Explaining variation in cancer survival between 11 jurisdictions in the International Cancer Benchmarking Partnership: a primary care based vignette study. BMJ Open, 5, e007212

Tørring ML, Frydenberg M, Hansen RP, Olesem F, Vedsted P (2013). Evidence of increasing mortality with longer diagnostic intervals for five common cancers: a cohort study in primary care. European Journal of Cancer, 49(9), 2187-2198.

Walter F, Webster A, Scott S, Emery J (2012). The Andersen model of total patient delay: a systematic review of its application in cancer diagnosis. Journal of Health Services Research and Policy, 17(2), $110-118$.

Walters S, Maringe C, Coleman MP, Peake MD, Butler J, Young N, Bergström S, Hanna L, Jakobsen E, Kölbeck K, Sundstrøm S, Engholm G, Gavin A, Gjerstorff ML, Hatcher J, Johannesen TB, Linklater KM, McGahan CE, Steward J, Tracey E, Turner D, Richards MA, Rachet B, the ICBP Module 1 Working Group (2013). Lung cancer survival and stage at diagnosis in Australia, Canada, Denmark, Norway, Sweden and the UK: a population-based cohort study, 2004-2007. Thorax, 68, $551-564$.

Walters S, Maringe C, Butler J, Rachet B, Barrett-Lee P, Bergh j, Boyages J, Christiansen P, Lee M, Warnberg F, Alleman C, Engholm G, Fornander T, Gjerstorff ML, Johannesen TB, Lawrence G, McGahan CE, Middleton R, Steward J, Tracey E, Turner D, Richards MA, Coleman MP, the ICBP Module 1 Working Group (2013). Breast cancer survival and stage at diagnosis in Australia, Canada, Denmark, Norway, Sweden and the UK, 2000-2007: a population-based study. British Journal of Cancer, 108, 1195-1208.

Weller D, Vedsted P, Rubin G, Walter FM, Emery J, Scott S, Campbell C, Andersem RS, Hamilton W, Olesen F, Rose P, Nafees S, van Rijswijk E, Hiom S, Muth C, Beyer M, Neal RD (2012). The Aarhus statement: Improving design and reporting of studies on early cancer diagnosis. British Journal of Cancer, 106(7), 1262-1267. 